\title{
Changes in lymphocyte subsets in patients with Guillain-Barré syndrome treated with immunoglobulin
}

\author{
Hui Qing Hou' ${ }^{1}$ Jun Miao ${ }^{2}$, Xue Dan Feng ${ }^{1}$, Mei Han ${ }^{3}$ Xiu Juan Song ${ }^{1}$ and Li Guo ${ }^{1 *}$
}

\begin{abstract}
Background: Guillain-Barré syndrome (GBS) is an autoimmune condition characterized by peripheral neuropathy. The pathogenesis of GBS is not fully understood, and the mechanism of how intravenous immunoglobulin (IVIG) cures GBS is ambiguous. Herein, we investigated lymphocyte subsets in patients with two major subtypes of GBS (acute inflammatory demyelinating polyneuropathy, AIDP, and acute motor axonal neuropathy, AMAN) before and after treatment with IVIG, and explored the possible mechanism of IVIG action.

Methods: Sixty-four patients with GBS were selected for our study and divided into two groups: AIDP $(n=38)$ and AMAN $(n=26)$. Thirty healthy individuals were chosen as the control group. Relative counts of peripheral blood $T$ and B lymphocyte subsets were detected by flow cytometry analysis.

Results: In the AIDP group, the percentage of $\mathrm{CD}^{+} \mathrm{CD} 45 \mathrm{RO}^{+} \mathrm{T}$ cells was significantly higher, while the percentage of $\mathrm{CD}^{+}{ }^{+} \mathrm{CD} 45 \mathrm{RA}^{+} \mathrm{T}$ cells was notably lower, than in the control group. After treatment with IVIG, the ratio of $\mathrm{CD}^{+} / \mathrm{CD}^{+} T$ cells and the percentage of $\mathrm{CD} 4^{+} \mathrm{CD} 45 \mathrm{RA}{ }^{+} T$ cells increased, while the percentages of CD8 ${ }^{+} T$ cells and $C D 4^{+} C D 45 R O^{+} T$ cells decreased significantly, along with the number of $C D 19^{+} \mathrm{B}$ cells. However, there were not such obvious changes in the AMAN group. The Hughes scores were significantly lower in both the AIDP and AMAN groups following treatment with IVIG, but the changes in Hughes scores showed no significant difference between the two groups.
\end{abstract}

Conclusions: This study suggested that the changes in T and B-lymphocyte subsets, especially in CD4 ${ }^{+}$T-lymphocyte subsets, might play an important role in the pathogenesis of AIDP, and in the mechanism of IVIG action against AIDP.

Keywords: Acute inflammatory demyelinating polyneuropathy, Acute motor axonal neuropathy, Guillain-Barré syndrome, Intravenous immunoglobulin, Lymphocyte subsets

\section{Background}

Guillain-Barré syndrome (GBS) is an acute, immunemediated attack on the peripheral nervous system that leads to flaccid paralysis, with a case fatality rate of $5-10 \%$ [1]. Both cellular and humoral immunity participate in the onset of GBS, though cellular immunity is the primary cause [2]. Based on clinical, electrophysiological, and pathologic characteristics, GBS can be divided into two major subtypes: AIDP (acute inflammatory demyelinating polyneuropathy, AIDP) and AMAN (acute motor

\footnotetext{
*Correspondence: guoli6105@163.com

1 Department of Neurology, the Second Hospital of Hebei Medical University, Key laboratory of Hebei Neurology, Shi jia zhuang, Hebei 050000, China Full list of author information is available at the end of the article
}

axonal neuropathy, AMAN) [3]. At present there is no specific treatment for GBS; intravenous immunoglobulin (IVIG) has been the drug of choice for GBS treatment because it provides the most effective clinical results $[4,5]$, with almost no contraindications.

Lymphocyte function is related to the numerous complex superficial cell membrane proteins on the cell surface. As a result, lymphocyte immune phenotype analysis can be used as an important reference index for evaluating the body's immune status. In recent years, much work has been undertaken to study the distribution of lymphocyte subsets in GBS, but the results are variable [6-9]. Our team found that the distribution of lymphocyte subsets differs greatly between individuals; therefore, it is important 
to test individual GBS patients both before and after IVIG treatment [5]. In the current study, we examined GBS in a population of individuals from northern China who developed AIDP or AMAN. This study used a matched-pairs design using each patient's own pre- and post-treatment data. We detected changes in $\mathrm{T}$ and $\mathrm{B}$ lymphocyte subset distribution, allowing us to explore the pathogenesis of GBS and speculate on the mechanism of IVIG in treating GBS.

\section{Methods}

\section{Patients}

All subjects (patients with AIDP or AMAN and healthy controls) were from northern China and were referred to the Second Hospital of Hebei Medical University in Shijiazhuang from 2010-2013. All patients fulfilled accepted diagnostic criteria [10], and were studied within 2 weeks of the onset of GBS. Sixty-four cases underwent electrophysiological examination, being recorded for motor conductive velocity (MCV), distal latency, F wave, and motor evoked amplitude [10-13], and were classified into two groups: AIDP $(n=38)$ and AMAN $(n=26)$. The primary outcome parameter was GBS disability (Hughes) scale score at discharge. Thirty subjects (age- and sexmatched controls) from the same area were also included in the study. Controls had no personal or family history of GBS, and no sign of any peripheral neuropathy. Controls were chosen randomly.

Peripheral blood was collected and T and B lymphocyte subset relative counts were detected by flow cytometry both before and after treatment with IVIG. This study protocol was approved by the Research Ethics Committee of the Second Hospital of Hebei Medical University and followed the ethical guidelines of the 1975 Declaration of Helsinki and all subsequent modifications [14]. All patients provided a written informed consent to participate in this research.

\section{Therapeutic method}

Patients were treated with IVIG $\left(0.4 \mathrm{~g} \cdot \mathrm{kg}^{-1} \cdot \mathrm{d}^{-1}\right)$ continuously for 5 days. At 3 weeks post-therapy, patients were again graded using the Hughes scale $[15,16]$.

\section{Flow cytometry}

Prior to therapy, and again within 24 hours of the final therapy with IVIG, whole blood was collected in EDTA vacutainer tubes. Cyflow reagents and consumables were used according to the manufacturer's protocol. The set comprised the following antibodies: CD4-APC/ CD8-PE/CD3-FITC; CD4-APC/CD45RA-FITC/CD45ROPE; CD19-FITC (Becton Dickinson, San Jose, CA, USA). Meanwhile, IgG1-FITC/IgG2a-PE was replied as isotype control. $100 \mu \mathrm{l}$ of the blood was incubated in tubes together with $20 \mu \mathrm{l}$ of the antibodies. The incubation was performed in the dark, at room temperature for $15 \mathrm{~min}$. After incubation, erythrocytes were subsequently lysed, and the cell suspension was centrifuged, washed three times, and resuspended in an appropriate volume of flow staining buffer. A minimum of 10,000 cells was accepted for FACS (BD Biosciences, San Jose, CA, USA) analysis. Cells were gated based on morphological characteristics.

\section{Analysis}

Statistical analyses were conducted using SPSS18.0 software, and continuous variables are expressed as mean \pm standard deviation $(\bar{x} \pm s)$. The mean differences between the two samples were analyzed using a t-test. The mean differences between the two patient groups before and after treatment were compared using a paired $\mathrm{t}$-test. The inspection level was $\alpha=0.05$ and differences were considered significant at $p<0.05$.

\section{Results}

The percentage of $\mathrm{CD}^{+}{ }^{+} \mathrm{CD} 45 \mathrm{RO}^{+} \mathrm{T}$ cells $(65.60 \pm 10.41$ vs $55.06 \pm 5.48$ ) was significantly higher, while the percentage of $\mathrm{CD}^{+} \mathrm{CD} 45 \mathrm{RA}^{+} \mathrm{T}$ cells $(29.10 \pm 10.13$ vs $39.24 \pm$ $6.25)$ was obviously lower $(p<0.05)$, in the AIDP group than in the control group, but there was no significant difference between samples drawn from the AMAN group (Figures 1 and 2).

In the AIDP group, the ratio of $\mathrm{CD} 4^{+} / \mathrm{CD}^{+} \mathrm{T}$ cells $(1.85 \pm 1.09$ vs $1.29 \pm 0.80)$ and the percentage of $\mathrm{CD} 4^{+}$ CD45RA ${ }^{+} \mathrm{T}$ cells $(37.56 \pm 9.22$ vs $29.10 \pm 10.13)$ increased significantly $(p<0.05)$, while the percentage of $\mathrm{CD}^{+} \mathrm{T}$ $(29.60 \pm 7.90$ vs $35.12 \pm 11.94), \mathrm{CD}^{+}{ }^{+} \mathrm{CD} 45 \mathrm{RO}^{+} \mathrm{T}(57.51 \pm$ 8.45 vs $65.60 \pm 10.41)$, and $\mathrm{CD} 19^{+} \mathrm{B}(12.11 \pm 4.58$ vs $15.89 \pm 3.41)$ cells significantly decreased $(p<0.05)$ after treatment. Again, there was not such a marked change following treatment in the AMAN group (Figures 3, 4, and 5).

The Hughes scores were significantly lower in both the AIDP and AMAN groups following treatment with IVIG $(p<0.05)$ (Table 1$)$.

The change in Hughes scores was $1.95 \pm 0.56$ in the AIDP group and $1.73 \pm 0.80$ in the AMAN group, and there was no significant difference between the two groups $(p>0.05)$

\section{Discussion}

Demyelination of motor and sensory nerves occurs in AIDP, whereas motor neurons evoke reduced amplitudes in AMAN, without demyelination. AIDP is an autoimmune disorder mediated by $\mathrm{T}$ and $\mathrm{B}$ lymphocyte systems. Pathologically, varying degrees of lymphocyte infiltration [17] and myelin sheath depigmentation can be found in AIDP, and the complement-mediated antibody attack on nerves is likely to play an important role in the pathogenesis of AIDP [18]. In AMAN, motor nerve axons, especially in Ranvier's 


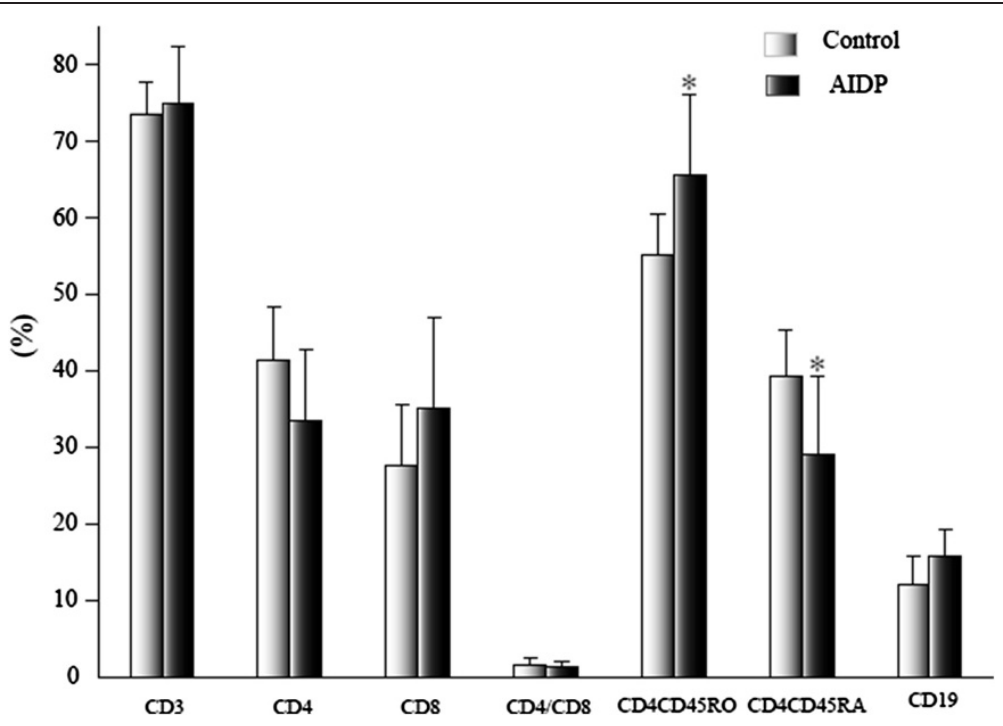

Figure 1 Comparison of lymphocyte subsets in AIDP and control groups before treatment. The data are mean \pm S.D. ${ }^{*} p<0.05$, relative to the control group.

section, are attacked by macrophages, with varying degrees of Wallace degeneration, but rarely with inflammation and demyelination [19,20]. The etiology of GBS is not clear; however, a possible relationship with certain infections and vaccination has been documented in several studies [21-23]. GBS frequently follows a variety of presumed viral and bacterial infections [24,25], and Campylobacter gastroenteritis is the single most identifiable agent associated with GBS (AMAN) [26]. In subjects with GBS from northern China who developed AIDP and AMAN, the DNA-based typing of the HLA class II alleles in the two subtypes demonstrated that HLA class II epitopes are not distributed equally [27].

According to their antigen recognition receptors, $\mathrm{T}$ lymphocytes can be classified into two groups: TCR $\alpha / \beta$ T cells and TCR $\gamma / \delta$ T cells. The former make up more than
$90 \%$ of $\mathrm{T}$ cells in peripheral blood. TCR $\alpha / \beta \mathrm{T}$ cells, which are composed of $\mathrm{CD} 3{ }^{+} \mathrm{CD} 4{ }^{+} \mathrm{CD} 8^{-} \mathrm{T}$ cells and $\mathrm{CD}^{+}{ }^{+} \mathrm{CD} 4{ }^{-} \mathrm{CD}^{+}{ }^{+} \mathrm{T}$ cells, play an important role in common immune response. $\gamma / \delta \mathrm{T}$ cells were discovered in the past decade, and make up $0.5-10 \%$ of T cells in peripheral blood. Most $\gamma / \delta$ T cells express $C D 3^{+} \mathrm{CD} 4^{-} \mathrm{CD} 8^{-} \mathrm{T}$, which can be activated in autoimmune diseases. $\mathrm{T}$ lymphocytes include helper $\mathrm{T}$ lymphocytes $\left(\mathrm{CD}^{+} \mathrm{T}\right)$ and killer $\mathrm{T}$ lymphocytes $\left(\mathrm{CD}^{+} \mathrm{T}\right)$. $\mathrm{CD} 4^{+} \mathrm{T}$ cells are heterogeneous, and include naive $\mathrm{T}$ cells and memory $\mathrm{T}$ cells, the former predominately expressing CD45RA and the latter expressing CD45RO [28,29]. In different stages of T cell development, different CD45 subtypes are expressed. Studies have shown that during the development of $\mathrm{T}$ cells in the thymus, a shift from CD45RO to CD45RA occurs, which

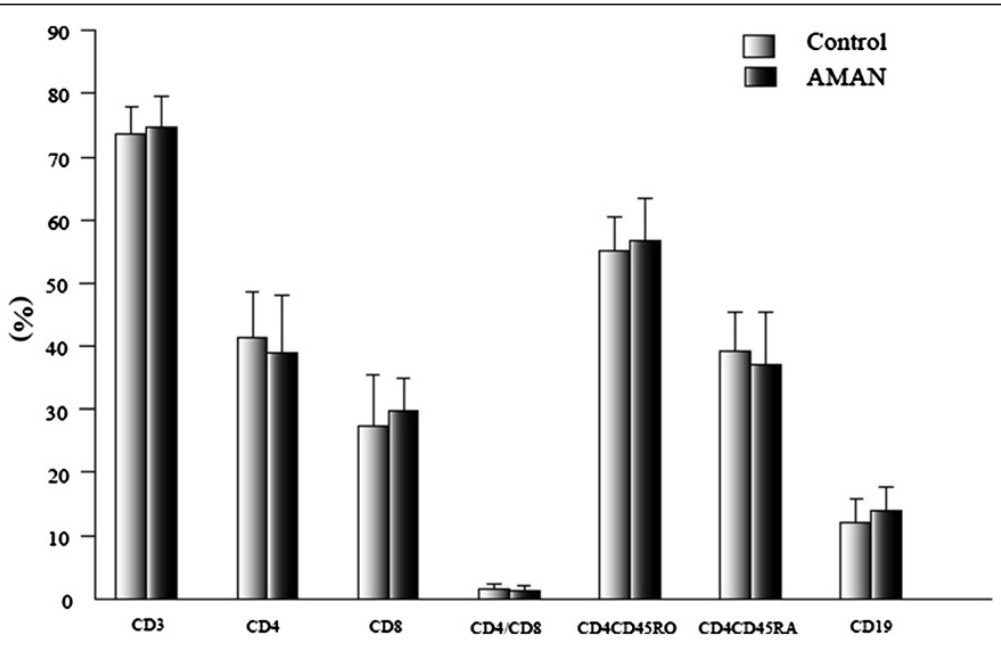

Figure 2 Comparison of lymphocyte subsets in AMAN and control groups before treatment. The data are mean \pm S.D. 


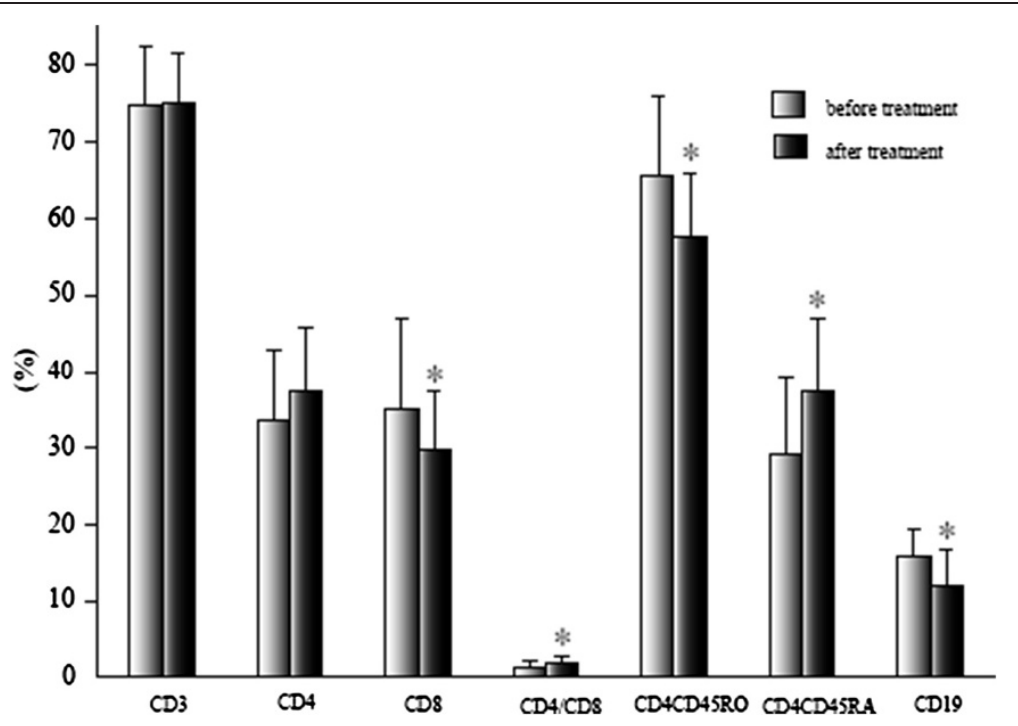

Figure 3 Comparison of lymphocyte subsets in AIDP before and after treatment. The data are mean \pm S.D. ${ }^{*} p<0.05$.

marks the completion of negative selection and helps to eliminate autoreactive $\mathrm{T}$ cells and prevent autoimmune disease [30]. In the peripheral blood, $\mathrm{CD}^{+} \mathrm{CD} 45 \mathrm{RA}^{+} \mathrm{T}$ cells can convert into $\mathrm{CD}^{+} \mathrm{CD} 45 \mathrm{RO}^{+} \mathrm{T}$ cells following stimulation by antigen [30]. CD45RA and CD45RO have distinct effects on the function of $\mathrm{B}$ cells, and $\mathrm{B}$ cells can also increase the proliferation of CD45RO, in contrast to a decreased proliferation of CD45RA [31]. CD19 is an idioantigen of B lymphocytes, which also participates in their activation and signal conduction.

Our previous investigation found that if the number of $\mathrm{CD}^{+} \mathrm{T}$ or $\mathrm{CD}^{+} \mathrm{T}$ cells, or the ratio between them, changed, then immune functions may become disordered leading to a disease state in patients with GBS [5]. Studies have also shown that the number of $\mathrm{CD}_{4}^{+} \mathrm{T}$ cells in patients with GBS decreased while $\mathrm{CD}^{+} \mathrm{T}$ cells increased, especially in the progressive stage. More specifically, $\mathrm{CD} 4{ }^{+} \mathrm{CD} 29^{+} \mathrm{T}$ cells (assist/induction of $\mathrm{CD} 4^{+} \mathrm{T}$ cells) increased and $\mathrm{CD} 4{ }^{+} \mathrm{CD} 45 \mathrm{RA}^{+} \mathrm{T}$ cells (restrain/induction of $\mathrm{CD} 4^{+} \mathrm{T}$ cells) decreased [6,7]. In contrast, other studies reported that the number of $\mathrm{CD}^{+} \mathrm{T}$ cells in patients with GBS increased and $\mathrm{CD}^{+} \mathrm{T}$ cells decreased $[8,9]$. Our previous study showed that following treatment with IVIG, $\mathrm{CD} 8^{+} \mathrm{T}$ and $\mathrm{CD} 4^{+} \mathrm{CD} 29^{+} \mathrm{T}$ cells decreased in patients with GBS, whereas CD4/CD8 and $\mathrm{CD} 4{ }^{+} \mathrm{CD} 45 \mathrm{RA}^{+} \mathrm{T}$ cells increased [5]. To understand the changes in lymphocyte subsets in different subtypes of GBS, we carried out a further study and divided GBS patients into AIDP and AMAN groups.

In AIDP, demyelination and lymphocyte infiltration are observed. However, there is very little inflammation and demyelination in AMAN. Our research showed that

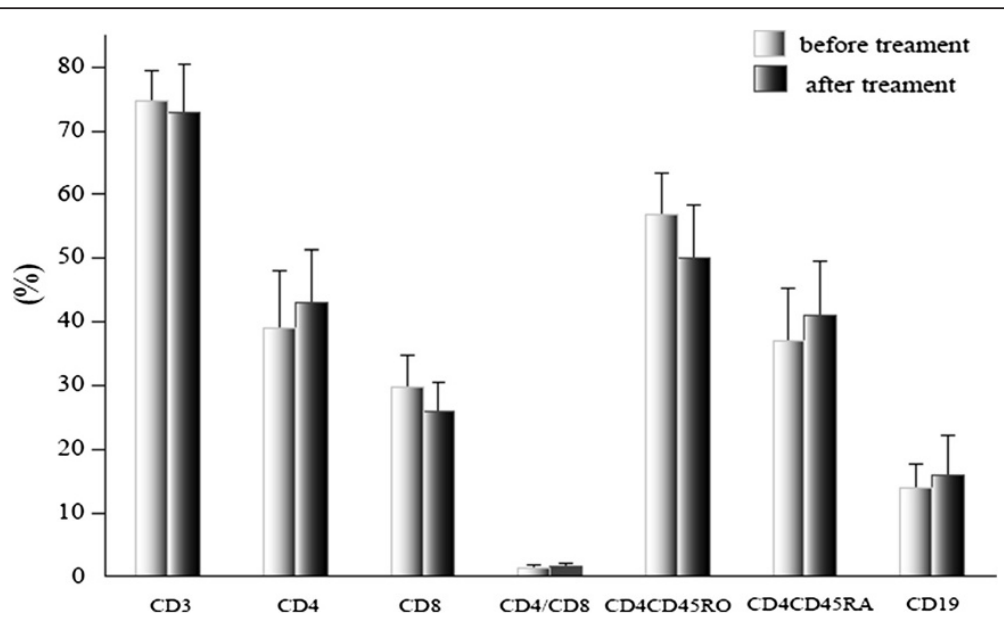

Figure 4 Comparison of lymphocyte subsets in AMAN before and after treatment. The data are mean \pm S.D. 


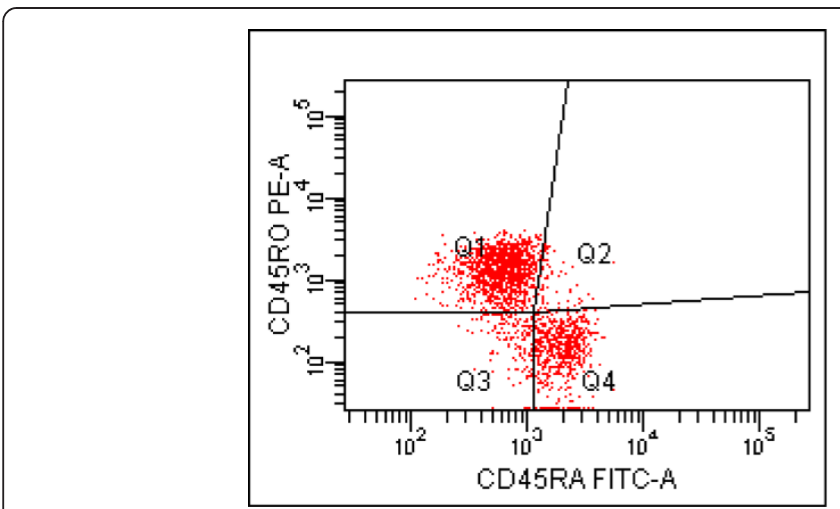

before treatment

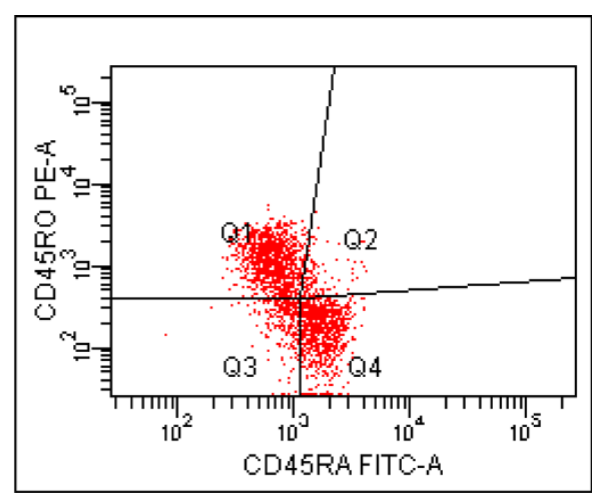

after treatment

Figure 5 Representative plots from individual patient from AIDP group, gated on CD4+. The number in each quadrant represents CD45RA and $C D 45 R O$ gated on CD4+.

the changes in lymphocyte subsets in the two GBS groups were different. In the AIDP group, the percentage of $\mathrm{CD}_{4}^{+} \mathrm{CD} 45 \mathrm{RA}^{+} \mathrm{T}$ cells was markedly lower, whereas the percentage of $\mathrm{CD}^{+}{ }^{+} \mathrm{CD} 45 \mathrm{RO}^{+} \mathrm{T}$ cells was significantly higher than in the control group. The reason for this may be that $\mathrm{CD}_{4}^{+} \mathrm{CD} 45 \mathrm{RA}^{+} \mathrm{T}$ cells transformed into $\mathrm{CD} 4$ ${ }^{+} \mathrm{CD} 45 \mathrm{RO}^{+} \mathrm{T}$ cells after activation by antigens in the peripheral blood. This result is consistent with a study that showed that CD45RO enters into the cell cycle earlier than CD45RA stimulated by growth factors [32]. The transformation suggested that cellular immunology, especially the change in $\mathrm{CD} 4^{+} \mathrm{T}$ cell subsets, might play an important role in the pathogenesis of AIDP.

Cortical hormone has been the drug of choice to treat GBS. However, research has shown that routine hormone treatment cannot prevent the progression of GBS or improve prognosis [33]. At present, large doses of IVIG are the foremost immunoregulatory therapeutic method, and can ameliorate the course of GBS progression $[5,34]$. After therapy with IVIG, the ratio of $\mathrm{CD} 4^{+} / \mathrm{CD} 8^{+}$ $\mathrm{T}$ and the percentage of $\mathrm{CD} 4{ }^{+} \mathrm{CD} 45 \mathrm{RA}^{+} \mathrm{T}$ cells increased, while the percentage of $\mathrm{CD}^{+} \mathrm{T}, \mathrm{CD} 4^{+} \mathrm{CD} 45 \mathrm{RO}^{+} \mathrm{T}$, and $\mathrm{CD} 19^{+} \mathrm{B}$ cells significantly declined in the AIDP group.

Table 1 Comparison of Hughes scores before and after treatment in each group $(\bar{x} \pm s)$

\begin{tabular}{lll}
\hline Group & Time & Hughes score \\
\hline AIDP & Before treatment & $3.59 \pm 0.45$ \\
$(\mathrm{n}=38)$ & After treatment & $1.32 \pm 0.67$ \\
& Falling value & 2.27 \\
& $p$ & $<0.05$ \\
AMAN & Before treatment & $4.12 \pm 0.63$ \\
$(\mathrm{n}=26)$ & After treatment & $2.47 \pm 0.82$ \\
& Falling value & 1.65 \\
& $p$ & $<0.05$ \\
\hline
\end{tabular}

We presumed that IVIG inhibited the toxic effects of CD8 killer $\mathrm{T}$ cells on the myelin of nerves in AIDP and by altering the distribution of $\mathrm{CD}^{+} \mathrm{T}, \mathrm{CD} 4^{+} \mathrm{CD} 45 \mathrm{RA}^{+} \mathrm{T}$, and $\mathrm{CD}^{+} \mathrm{CD} 45 \mathrm{RO}^{+} \mathrm{T}$ cells, IVIG reduced the total number of B lymphocytes. Therefore, IVIG might affect the production of autoantibodies and decrease inflammatory cell infiltration, and we found Hughes scale score was significantly lower after treatment, this result suggested IVIG could suppress peripheral nerve injury and encourage neurofunctional recovery mediated by increasing CD45RA T cell and decreasing CD45RO T cell.

In the AMAN group, changes were not significant. That is, less inflammation and demyelination were present. Although IVIG suppressed immune reactions to a certain degree and prevented aggravation of the condition, our study showed no association between the immune parameters investigated and IVIG. These findings hint that there might be other changes in immune function, and further studies are needed.

The Hughes scale score was significantly lower both in the AIDP and AMAN groups after therapy with IVIG, and the change in the score was not significantly different between the AIDP and AMAN groups. Although this study cannot explain the pathogenicity of AMAN and the mechanism by which IVIG treats it, the effect of IVIG curing AMAN is evident. Therefore, in our clinical setting, we propose administering full doses of IVIG to patients with AIDP and AMAN at the earliest stage. This might prevent aggravation of the condition, decrease paralysis of respiratory muscle, prevent tracheal incision, preclude complications, and encourage the recovery of function of damaged neurology as soon as possible.

A search of the literature found very different conclusions on lymphocyte subgroup detection in patients with GBS. We designed this study of GBS patients to make patients their own controls, before and after treatment. 
Such design can preclude the impact of different individuals who have suffered from infection previously. Furthermore, it can reveal the impact of disease and IVIG intervention on the immune system of an individual. GBS can be classified into two major groups: AIDP and AMAN. These groups differ in their hematological and immunological pathogenesis. Consequently, when studying lymphocyte subsets in GBS, it is important to classify GBS into AIDP or AMAN, and use patients as their own controls, before and after treatment, to minimize the effects of variation on the results.

\section{Conclusions}

This study suggested that the changes in $\mathrm{CD}_{4}^{+} \mathrm{T}$-lymphocyte subsets might play an important role in the pathogenesis of AIDP. After treatment with IVIG, the changes in T and B-lymphocyte subsets are significant and also might play an important role in the mechanism of IVIG action against AIDP. But there were not such changes in AMAN, this study might infer that the pathogenesis and the mechanism of IVIG action against two subjects of GBS(AIDP and AMAN) are different and further studies are needed to expound these problems.

\section{Competing interests}

The authors declare that they have no competing interests.

\section{Authors' contributions}

$H H Q, M J, G L:$ substantially contributed to the drafting and revision of the manuscript, study concept and design, analysis and interpretation of data, and acquisition of data. FXD, SXJ: substantially contributed to the study concept and design and acquisition of data. HM: substantially contributed to the revision of the manuscript, study concept, and design. All authors read and approved the final manuscript.

\section{Financial disclosures}

Hou Hui Qing, Miao Jun, Feng Xue Dan, Han Mei, and Song Xiu Juan have no disclosures to report. Guo Li received research funding from the Second Hospital of HeBei Medical University.

\section{Author details}

'Department of Neurology, the Second Hospital of Hebei Medical University, Key laboratory of Hebei Neurology, Shi jia zhuang, Hebei 050000, China. 2Department of Neurosurgery, the General Hospital of North China

Petroleum Administration Bureau, Ren qiu, HeBei 062550, China. ${ }^{3}$ Emergency Department, the Second Hospital of Hebei Medical University, Shi jia zhuang, Hebei 050000, China.

Received: 30 August 2013 Accepted: 2 October 2014

Published online: 15 October 2014

\section{References}

1. Yuki N: Infectious origins of, and molecular mimicry in, Guillain-Barre and Fisher syndromes. Lancet Infect Dis 2001, 1(1):29-37.

2. Ariga T, Yu RK: Antiglycolipid antibodies in Guillain-Barre syndrome and related diseases: review of clinical features and antibody specificities. J Neurosci Res 2005, 80(1):1-17.

3. Griffin JW, Li CY, Ho TW, Xue P, Macko C, Gao CY, Yang C, Tian M, Mishu B, Cornblath DR: Guillain-Barre syndrome in northern China. The spectrum of neuropathological changes in clinically defined cases. Brain 1995, 118(Pt 3):577-595.

4. Hughes RA, Swan AV, Raphael JC, Annane D, van Koningsveld R, van Doorn PA: Immunotherapy for Guillain-Barre syndrome: a systematic review. Brain 2007, 130(Pt 9):2245-2257.
5. Guo L, Hou HQ, Song XJ, Yang JC, Gao CY: Change of T-Lymphocyte subsets in the patients with Gullain-Barre syndrome between pre and posttherapy with intravenous immunoglobulin and its meaning. Chin J Neurol 2008, 41(2):87-90.

6. Dahle C, Vrethem M, Ernerudh J: T lymphocyte subset abnormalities in peripheral blood from patients with the Guillain-Barre syndrome. J Neuroimmunol 1994, 53(2):219-225.

7. Sindern E, Oreja-Guevara C, Raulf-Heimsoth M, Baur X, Malin JP: A longitudinal study of circulating lymphocyte subsets in the peripheral blood during the acute stage of Guillain-Barre syndrome. J Neurol Sci 1997, 151(1):29-34.

8. Hughes RA, Aslan S, Gray IA: Lymphocyte subpopulations and suppressor cell activity in acute polyradiculoneuritis (Guillain-Barre syndrome). Clin Exp Immunol 1983, 51(3):448-454.

9. Lisak RP, Zweiman B, Guerrero F, Moskovitz AR: Circulating T-cell subsets in Guillain-Barre syndrome. J Neuroimmunol 1985, 8(2-3):93-101.

10. Cui $L Y, P u C Q, H u X Q$ : The diagnosis and treatment guidelines of Guillain-Barre syndrome in China. Chin J Neurol 2010, 43(8):583-586.

11. Asbury AK, Cornblath DR: Assessment of current diagnostic criteria for Guillain-Barre syndrome. Ann Neurol 1990, 27(Suppl):S21-S24.

12. Van den Bergh PY, Pieret F: Electrodiagnostic criteria for acute and chronic inflammatory demyelinating polyradiculoneuropathy. Muscle Nerve 2004, 29(4):565-574.

13. Van der Meche FG, Van Doorn PA, Meulstee J, Jennekens FG: Diagnostic and classification criteria for the Guillain-Barre syndrome. Eur Neurol 2001, 45(3):133-139.

14. Puri KS, Suresh KR, Gogtay NJ, Thatte UM: Declaration of Helsinki, 2008: implications for stakeholders in research. J Postgrad Med 2009, 55(2):131-134.

15. Hughes RA, Newsom-Davis JM, Perkin GD, Pierce JM: Controlled trial prednisolone in acute polyneuropathy. Lancet 1978, 2(8093):750-753.

16. Peng M, Jia JP: Predictors at nadir of severity on patients with Guillain-Barre syndrome. Chin J Neurol 2004, 37(2):154-157.

17. Asbury AK, Arnason BG, Adams RD: The inflammatory lesion in idiopathic polyneuritis. Its role in pathogenesis. Medicine (Baltimore) 1969, 48(3):173-215.

18. Hafer-Macko CE, Sheikh KA, Li CY, Ho TW, Cornblath DR, McKhann GM, Asbury AK, Griffin JW: Immune attack on the Schwann cell surface in acute inflammatory demyelinating polyneuropathy. Ann Neurol 1996, 39(5):625-635.

19. Feasby TE, Gilbert JJ, Brown WF, Bolton CF, Hahn AF, Koopman WF, Zochodne DW: An acute axonal form of Guillain-Barre polyneuropathy. Brain 1986, 109(Pt 6):1115-1126.

20. Feasby TE, Hahn AF, Brown WF, Bolton CF, Gilbert JJ, Koopman WJ: Severe axonal degeneration in acute Guillain-Barre syndrome: evidence of two different mechanisms? J Neurol Sci 1993, 116(2):185-192.

21. Greene SK, Rett MD, Vellozzi C, Li L, Kulldorff M, Marcy SM, Daley MF, Belongia EA, Baxter R, Fireman BH, Jackson ML, Omer SB, Nordin JD, Jin R, Weintraub ES, Vijayadeva V, Lee GM: Guillain-Barre syndrome, influenza vaccination, and antecedent respiratory and gastrointestinal infections: a case-centered analysis in the vaccine safety datalink, 2009-2011. PLOS ONE 2013, 8(6):e67185.

22. Souayah N, Yacoub HA, Khan HM, Farhad K, Mehyar LS, Maybodi L, Menkes DL, Qureshi Al: Guillain-Barre syndrome after influenza vaccination in the United States, a report from the CDC/FDA vaccine adverse event reporting system (1990-2009). J Clin Neuromuscul Dis 2012, 14(2):66-71.

23. Dieleman J, Romio S, Johansen K, Weibel D, Bonhoeffer J, Sturkenboom M: Guillain-Barre syndrome and adjuvanted pandemic influenza A (H1N1) 2009 vaccine: multinational case-control study in Europe. BMJ 2011, 343:d3908.

24. van Doorn PA, Ruts $L$, Jacobs $B C$ : Clinical features, pathogenesis, and treatment of Guillain-Barre syndrome. Lancet Neurol 2008, 7(10):939-950.

25. Lunn MP, Willison HJ: Diagnosis and treatment in inflammatory neuropathies. J Neurol Neurosurg Psychiatry 2009, 80(3):249-258.

26. Drenthen J, Yuki N, Meulstee J, Maathuis EM, van Doorn PA, Visser GH, Blok JH, Jacobs BC: Guillain-Barre syndrome subtypes related to Campylobacter infection. J Neurol Neurosurg Psychiatry 2011, 82(3):300-305.

27. Magira EE, Papaioakim M, Nachamkin I, Asbury AK, Li CY, Ho TW, Griffin JW McKhann GM, Monos DS: Differential distribution of HLA-DQ beta/DR beta epitopes in the two forms of Guillain-Barre syndrome, acute motor axonal neuropathy and acute inflammatory demyelinating polyneuropathy (AIDP): identification of DQ beta epitopes associated with susceptibility to and protection from AIDP. J Immuno/ 2003, 170(6):3074-3080. 
28. McBreen $S$, Imlach S, Shirafuji T, Scott GR, Leen C, Bell JE, Simmonds P: Infection of the CD45RA+ (naive) subset of peripheral CD8+ lymphocytes by human immunodeficiency virus type 1 in vivo. J Virol 2001, 75(9):4091-4102.

29. Clement LT, Vink PE, Bradley GE: Novel immunoregulatory functions of phenotypically distinct subpopulations of CD4+ cells in the human neonate. J Immunol 1990, 145(1):102-108.

30. MCNeill L, Cassady RL, Sarkardei S, Cooper JC, Morgan G, Alexander DR: CD45 isoforms in T cell signalling and development. Immunol Lett 2004, 92(1-2):125-134.

31. Matto M, Nuutinen UM, Ropponen A, Myllykangas K, Pelkonen J: CD45RA and $\mathrm{RO}$ isoforms have distinct effects on cytokine- and B-cell-receptormediated signalling in human B cells. Scand J Immunol 2005, 61(6):520-528.

32. Booth NJ, McQuaid AJ, Sobande T, Kissane S, Agius E, Jackson SE, Salmon M, Falciani F, Yong K, Rustin MH, Akbar AN, Vukmanovic-Stejic M: Different proliferative potential and migratory characteristics of human CD4+ regulatory T cells that express either CD45RA or CD45RO. J Immunol 2010, 184(8):4317-4326.

33. Hughes RA, Cornblath DR: Guillain-Barre syndrome. Lancet 2005, 366(9497):1653-1666

34. Douglas MR, Winer JB: Guillain-Barre syndrome and its treatment. Expert Rev Neurother 2006, 6(10):1569-1574.

doi:10.1186/s12883-014-0202-3

Cite this article as: Hou et al: Changes in lymphocyte subsets in patients with Guillain-Barré syndrome treated with immunoglobulin. BMC Neurology 2014 14:202.

\section{Submit your next manuscript to BioMed Central and take full advantage of:}

- Convenient online submission

- Thorough peer review

- No space constraints or color figure charges

- Immediate publication on acceptance

- Inclusion in PubMed, CAS, Scopus and Google Scholar

- Research which is freely available for redistribution 